Niepełnosprawność. Dyskursy pedagogiki specjalnej

Nr 34/2019

Disability. Discourses of special education

No. 34/2019

Sebastian Mrózek

Uniwersytet Śląski w Katowicach

\title{
Typy wsparcia społecznego osób z niepełnosprawnością zapisane w strategiach rozwoju gmin i w strategiach rozwiązywania problemów społecznych - analiza problematyki w dobie inkluzji
}

Jednostki samorządu terytorialnego powinny być pionierami i inicjatorami dobrych praktyk na rzecz osób z niepełnosprawnością. Ponadto, samorządy lokalne przyjmując rolę "małych ojczyzn", są zobowiązane w kompleksowy sposób troszczyć się o niepełnosprawnych mieszkańców. Celem niniejszego artykułu jest wstępne rozpoznanie problematyki wsparcia społecznego wobec osób niepełnosprawnych deklarowanego przez gminy w Strategiach rozwoju gmin i w Strategiach rozwiązywania problemów społecznych oraz przyporządkowanie jego szczegółowych form do poszczególnych typów wsparcia społecznego. W artykule została zaprezentowana analiza działań wspierających, jakie w dobie kultury inkluzyjnej oferują samorządy lokalne.

Słowa kluczowe: osoba z niepełnosprawnością, polityka społeczna, strategie rozwoju, strategie rozwiązywania problemów społecznych, kultura inkluzyjna

\section{Types and forms of social support for people with disabilities recorded in community development strategies and strategies for solving social problems - analysis of problems in the era of inclusion}

Local government units should be pioneer and initiators of good practices for people with disabilities. Additionally local governments assuming the role of "small homelands" are obligated to take care in a comprehensive way about disabled residents. The aim of the study is preliminary recognition of the issues of social support toward persons with disabilities declared by communities in Community development strategies and Strategies for solving social problems and to assign its detailed forms to several types of social support. The article presents what concrete supporting activities in the time of inclusive culture local governments.

Keywords: person with disability, social policy, community development strategies, strategies for solving social problems, inclusive culture 


\section{Wprowadzenie}

Wsparcie i pomoc udzielane w sytuacji trudnej należą do fundamentalnych działań warunkujących jej przezwyciężenie lub częściowe zmniejszenie negatywnych konsekwencji, które ze sobą niesie. By jednak tak się stało, istnieć muszą zasoby wsparcia, z których można korzystać. Przynależność człowieka do trwałych zbiorowości społecznych pozwala mu zaspokoić potrzebę bezpieczeństwa czy kształtowania własnej tożsamości. Działa to na niego w sposób wartościujący podnosząc poczucie własnej wartości, jego społeczną samoocenę, warunkuje odpowiedni poziom innych, wynikających z natury ludzkiej potrzeb biopsychicznych (Karwowska 2003: 9). Umożliwia osiągnięcie stanu równowagi - homeostazy. Wchodzenie $w$ interakcje i ich podejmowanie ma dla człowieka jeszcze jeden zasadniczy powód. Są nim sieci wzajemnych powiązań tworzone między ludźmi, które z kolei zabezpieczają wsparcie społeczne jednostki w sytuacjach trudnych. Za taką sytuację trudną uważa się między innymi niepełnosprawność czy chorobę (zob. np. Kowalik 2003: 797-820).

Niepełnosprawność czy długotrwała choroba wciąż są traktowane przez otoczenie jako niekorzystny fakt społeczny. Zjawiska te u ludzi pełnosprawnych nadal potrafią wywołać obawy, uczucie zakłopotania czy bezradność. Przyczynia się to do porzucania form pomocowych $w$ wyniku obawy posądzenia o niefachowe działania czy też (niestety wciąż) z powodu uprzedzeń. Sytuacja taka ma miejsce mimo postępu jaki został poczyniony w tej tematyce. Chodzi o ciągłe obalanie fałszywych stereotypów (Lejzerowicz, Książkiewicz 2012: 101-108), integrację społeczną z osobami niepełnosprawnymi czy szczególnie $\mathrm{w}$ obecnych czasach, związany z włączaniem społecznym czy edukacyjnym osób z niepełnosprawnością, rozwój kultury inkluzyjnej (por: Fidelus 2016). Bywa, że względu na swoją niepełnosprawność osoby te są traktowane w sposób przedmiotowy, a ich godność umniejszana (np. Kauffman i in. 2004). Paradoksem jest jednak fakt, że szczególnie wtedy osoby niepełnosprawne bądź chore tej pomocy i wsparcia potrzebują. Nawet niekoniecznie profesjonalnej, lecz może przede wszystkim świadczącej o obecności w ich pobliżu drugiego człowieka (Kirenko 2004: 11). Drogę godną do naśladowania $\mathrm{w}$ takich sytuacjach powinny prezentować przede wszystkim samorządy terytorialne troszczące się o sprawy bytowe swoich mieszkańców.

W dobie inkluzji społecznej osób z niepełnosprawnością wsparcie jest jednym z determinantów tego procesu, nieodłącznie z nim związanym. Oprócz zasobów osobistych jednostki niebagatelną rolę pełnią zasoby społeczne. To właśnie sieć wsparcia, na którą składają się: rodzina, znajomi, instytucje oraz organizacje. Warunkują kompensację brakujących $\mathrm{w}$ danym momencie potrzeb oraz sprzyjają 
pełniejszemu włączeniu osób z niepełnosprawnością w życie społeczne (Brzezińska i in. 2010: 79).

Celem niniejszego artykułu jest wstępne rozpoznanie problematyki wsparcia społecznego deklarowanego przez gminy w Strategiach rozwoju i w Strategiach rozwiązywania problemów spotecznych oraz przyporządkowanie szczegółowych form wsparcia do nadrzędnych jego typów. Podjęto więc próbę cząstkowej analizy tej tematyki. Szczególnie interesująco przedstawia się zagadnienie dotyczące skonkretyzowanych działań wspierających o charakterze włączającym, oferowanych przez samorządy terytorialne gmin wobec niepełnosprawnych mieszkańców.

Prezentowane opracowanie składa się z trzech zasadniczych części. W pierwszej z nich dokonana została fragmentaryczna charakterystyka gminnych strategii rozwoju i rozwiązywania problemów społecznych oraz funkcji jakie powinny pełnić (w szczególności działań pomocowych). Część druga prezentuje problematykę wsparcia społecznego na podstawie literatury przedmiotu. Z kolei część trzecia, stanowiąca meritum opracowania, obejmuje wyniki badań własnych na temat typów i form wsparcia społecznego oferowanego przez gminy w dokumentach strategicznych. Całość podsumowuje zakończenie.

\section{Strategie rozwoju gmin i Strategie rozwiązywania problemów społecznych}

Potrzeba wsparcia społecznego dla osób niepełnosprawnych jest szczególnie uzasadniona. Również od samorządu lokalnego wymagane jest organizowanie specjalistycznych działań i przedsięwzięć wspierających osoby z niepełnosprawnością. Działania te powinny być prowadzone nie tylko przez wyznaczonych do tego profesjonalistów, ale ich celem przede wszystkim stać się ma aktywizacja lokalnej społeczności oraz zwiększenie społecznej świadomości na temat problematyki funkcjonowania osób z niepełnosprawnością.

Definicja pojęcia "strategia” była określana głównie przez pryzmat działań taktycznych oraz wojennych, np. „sposób przygotowania i prowadzenia wojny, kampanii i operacji wojennych; dziedzina sztuki wojennej obejmująca te zagadnienia" lub w nieco bardziej ogólny sposób: „zaplanowany sposób prowadzenia jakichś działań zwykle na wielką skalę i długotrwałych, wyróżnia się między innymi strategie gospodarcze, ekonomiczne czy uzdrawiania finansów firmy" (Sobol 2003: 964). Obecnie to właśnie w obszarze przedsiębiorczym czy zarządzającym strategie znajdują zastosowanie: „(...) przedsiębiorstwo realizując strategię oczekuje korzyści i wykonania zamierzonych działań" (Encyklopedia Zarzadzania, https://mfiles.pl/pl/index.php/Strategia, dostęp: 03.2018). 
Kreowanie oraz planowanie strategii wraz z późniejszym jej wdrożeniem i monitoringiem rezultatów mają niebagatelne znaczenie także we współczesnej polityce społecznej. Ruchy polegające na wprowadzaniu do polityki społecznej rozwiązań, które udowodniły swoją skuteczność w sektorze komercyjnym czy biznesowym mają w Europie Zachodniej miejsce od co najmniej trzech dziesięcioleci, zaś w Polsce od około dekady. Profesjonalizacja tendencji strategicznych w polityce społecznej, oprócz poszukiwania nowych rozwiązań i biznesowych metod, które mogą mieć pozytywny oddźwięk na planowanie publicznej polityki społecznej wynikła również z interdyscyplinarności oraz dyfuzji nauk społecznych. Poddając analizie dowolny dokument strategiczny należy się więc spodziewać odnalezienia w nim: precyzyjnie określoną grupę adresatów planowanych działań, jasno zdefiniowany przedmiot dystrybucji i walory kwalifikacyjne, oraz możliwości tych, którzy mają strategię zrealizować. Strategia musi więc wyznaczać pole współpracy i jasno angażować konkretne podmioty do zrealizowania postawionych celów (Grewiński, Karwacki 2009: 11-18).

Strategie polityki społecznej konstruowane są na poziomie ogólnokrajowym lub lokalnym. Zwykle wpisują się w szersze strategie rozwoju miast, gmin, instytucji lub stowarzyszeń. Określają one lokalną politykę społeczną gminy na konkretne lata $\mathrm{w}$ wielu obszarach związanych $\mathrm{z}$ dalszym rozwojem oraz są inicjatorem pożądanych działań społecznych. Bywa, że ich powstanie wymuszone zostaje przez legislacje lub oczekiwania instytucji, które dysponują odpowiednimi funduszami mogącymi obecnie lub w przyszłości być przeznaczonymi na rozwój danej gminy. Wtedy ich znaczenie jest mocno hipotetyczne i postulatywne. Jednak starannie opracowana strategia, która w sposób jasny i precyzyjny określa konkretne działania wraz ze wskaźnikami ich oceny/realizacji stanowi dokument mający istotne znaczenie $\mathrm{w}$ kreowaniu przedsięwzięć oraz działań pomocowych także obejmujących osoby niepełnosprawne (Gajdzica 2015: 14-15).

Jak podkreśla Zenon Gajdzica "Jednostki samorządu terytorialnego obligowane są do działań $w$ wielu zakresach na rzecz rozwoju osób $\mathrm{z}$ niepełnosprawnością. Zbiór ich kompetencji oraz zadań został sprecyzowany w ustawach oraz uszczegółowiony $\mathrm{w}$ rozporządzeniach i odpowiednio przypisany wszystkim szczeblom samorządu terytorialnego" (Gajdzica 2015: 15; por.: Kołaczek 2010). Zależnie od wybranej typologii konstruowania strategii na poszczególnych poziomach zadania te mogą być jej nieodłączną częścią lub zostać potraktowane jako mniej istotne i zmarginalizowane. Same jednostki samorządu terytorialnego mogą także realizować zadania na rzecz osób niepełnosprawnych i poprawy ich sytuacji życiowej poprzez np. podejmowanie współpracy z organizacjami pożytku publicznego, fundacjami, stowarzyszeniami (Gajdzica 2015: 15).

Znaczenie z punktu widzenia sytuacji osób niepełnosprawnych oraz możliwości udzielanego im wsparcia mogą mieć dwa typy dokumentów strategicz- 
nych: chodzi tutaj o Strategie rozwoju gmin oraz Strategie rozwiazywania problemów społecznych. Są to dokumenty uchwalane na posiedzeniach rady gmin zwykle na okres określonej kadencji (zazwyczaj jest to kilka lat) podejmujące lub proponujące wdrażanie nowych/kontynuację dotychczasowych działań, których adresatami są grupy społeczne - także niepełnosprawni czy długotrwale chorzy. Określają one możliwości wsparcia i pomocy, zasoby, którymi gmina dysponuje cele i działania (więcej na ten temat: Gajdzica, Mrózek 2017), mocne i słabe strony wraz z szansami i zagrożeniami1.

\section{Problematyka wsparcia społecznego}

\section{Definicja wsparcia społecznego}

Dotychczas podejmowano już wielu prób zdefiniowania wsparcia społecznego. Zazwyczaj kończyły się one rezultatem ujmującym to pojęcie/zjawisko jako szczególnie wieloznaczne i trudne do wyjaśnienia w jednej, konkretyzującej definicji. Wsparcie społeczne nie jest zarezerwowane tylko dla sytuacji trudnych, związanych z życiowym stresem czy przeżywaniem poważanych trudności. Postrzegane bowiem jest jako pewna stała właściwość w relacjach służąca przystosowaniu i zdrowiu człowieka. Obecnie problematykę wsparcia społecznego traktuje się jako typ zachowań pomocowych głównie poprzez analizę motywów pomagania, wzajemności pomocy i tego w jaki sposób funkcjonuje altruizm. (Sęk, Cieślak 2012: 11-13).

Przyjmuje się, że „wsparcie społeczne obejmuje więc wszelkie możliwe rodzaje pomocy, począwszy od pomocy emocjonalnej, informacyjnej i materialnej, a skończywszy na świadczeniu usług. (...) Możliwość skorzystania ze wsparcia zależy nie tylko od chęci osoby, która jej potrzebuje, ale także od aktywności w tym zakresie społeczności lokalnej" (Stońska, Misiuna 1993: 12).

\section{Typy wsparcia społecznego}

W procesie społecznej interakcji zawsze wyróżnia się pewną treść wymiany społecznej. W zależności od tego czym owa treść jest i jaki przybiera charakter pojawiają się różne typologie wsparcia społecznego. Najbardziej adekwatna i przejrzysta wydaje się jednak typologia wsparcia społecznego zaproponowana przez Helenę Sęk (także z punktu widzenia badań powstałych na rzecz niniejszego

\footnotetext{
1 Przykładowo: Strategia Rozwoju Gminy Łodygowice na lata 2014-2020 (http://www.lodygowice.pl /i/images/file/bar573.pdf, dostęp: 03.2018) oraz Strategia Rozwiązywania Problemów Społecznych Gminy Eodygowice na lata 2014-2024 (http://www.lodygowice.pl/!data/dokumenty/program\%20pomocy \%20dziecku\%20i\%20rodzinie.pdf, dostęp: 03.2018).
} 
tekstu). W swoim zakresie wydaje się być odpowiednio kompleksowa i na tyle wieloaspektowa by w wyczerpujący sposób rozpatrzeć możliwe obszary działań wspierających. Najczęściej wsparcie społeczne dzielone jest bowiem na (Sęk, Cieślak 2012: 18-19):

1. Wsparcie emocjonalne - polegające w największej mierze na przekazywaniu emocji podtrzymujących w toku interakcji. Mają one charakter uspokajający, podkreślający troskę, pozytywny stosunek do osoby wspieranej. Przyjmuje się, że wsparcie emocjonalne jest najpowszechniejszym rodzajem wsparcia społecznego.

2. Wsparcie informacyjne - bywa też określane mianem wsparcia poznawczego. Polega na wymianie informacji w toku interakcji. Chodzi o informacje, które mogą pomóc osobie wspieranej w lepszym zrozumieniu własnej sytuacji życiowej oraz problemu. Ponadto ważne jest też dostarczenie zwrotnych informacji na temat skuteczności podejmowania przez osobę wspierającą działań zaradczych.

3. Wsparcie instrumentalne - przyjmuje postać instruktażu, który także może polegać na przekazywaniu informacji o poszczególnych sposobach postępowania, ale także powinien modelować skuteczne rodzaje zachowań zaradczych.

4. Wsparcie rzeczowe (materialne) - to pomoc o charakterze materialnym, finansowym, rzeczowym oraz bezpośrednie działania na rzecz osób potrzebujących: przekazywanie środków życiowych, dożywianie, udostępnianie schronienia, mieszkania, zaopatrywanie w lekarstwa.

5. Wsparcie duchowe - odwołuje się głownie do opieki hospicyjnej, paliatywnej. Tam pomoc wobec cierpienia i bólu egzystencjalnego wymaga sięgnięcia do tematyki sensu i ducha.

Mnogość obecnie stosowanych typów i bardziej szczegółowych form wsparcia społecznego może więc znacznie odmienić sytuację osób znajdujących się w potrzebie. Należy jednak zdawać sobie sprawę z tego, że nieodpowiedzialny i niekonsekwentny dobór działań wspierających - pomimo dobrych chęci przyczyni się do pogłębienia zagrożeń oraz trudności. Być może dlatego właśnie tak upowszechniły się w obszarze polityki społecznej działania o charakterze strategicznym. Strategii nie można przygotować, a przynajmniej nie powinno w sposób pobieżny. Jest to procedura długotrwała i wieloaspektowa, zaprojektowana $\mathrm{w}$ ten sposób by ryzyko zminimalizować, przewidzieć wszystkie scenariusze, odpowiedzialnie dobrać rozwiązania wraz z alternatywami, co w ostateczności prawdopodobnie przyczyni się do osiągnięcia pożądanego stanu rzeczy.

Z kolei spotkać można się również z twierdzeniem, że naturalne sieci wsparcia społecznego są skuteczniejsze i korzystniejsze, ponieważ nie przypisuje im się znamion stygmatyzacji, nie wiążą się z kosztami, a ich dostępność jest zdecydo- 
wanie łatwiejsza. Mowa tutaj przede wszystkim o sieciach rodzinnych, pozarodzinnych czy innych opartych na dobrowolnym działaniu (np. Solomon i in. 1987).

Wsparcie społeczne ujmowane jest więc jako dynamiczna, wieloaspektowa działalność o znamionach pomocowych i motywujących do przezwyciężenia sytuacji trudnych. Aby było skuteczne konieczny jest kompleksowy dobór jego form szczegółowych do sytuacji, w której znajduje się podmiot wsparcia wymagający. Może ono przybrać formę zinstytucjonalizowaną bądź opartą tylko na partnerskich relacjach międzyludzkich. Z punktu widzenia osób z niepełnosprawnością i ich sytuacji społecznej niezwykle ważne jest na jaką pomoc i z czyjej strony mogą liczyć przykładowo na terytorium środowiska zamieszkania - danej gminy czy powiatu.

\section{Założenia badań własnych}

Postępujący proces decentralizacji uprawnień i publicznych pieniędzy przyczynił się do przekazania władzy na szczebel lokalny, czyniąc jednostki samorządu terytorialnego bardziej autonomicznymi w zakresie samodzielnego podejmowania decyzji oraz rozstrzygania miejscowych problemów. W środowiskach popularne jest więc tworzenie idei "małych ojczyzn”, których źródłem dopatrywać się można $\mathrm{w}$ rozmiarach przejawianej aktywności i zaangażowaniu w otaczający świat (Przecławska, Theiss 1996). Obecnie samorząd terytorialny jest podmiotem najbliższym i najbardziej zorientowanym w sytuacji socjalno-bytowej niepełnosprawnych mieszkańców. Jest więc odpowiedzialny za trafne dostosowanie metod działania i decyzji budżetowych to realnych potrzeb umożliwiających partycypację osób niepełnosprawnych w życiu środowiska lokalnego (Lejzerowicz, Książkiewicz 2012: 127). W zakresie podjętej tematyki badawczej interesująco prezentują się przede wszystkim kwestie związane z typami wsparcia społecznego/działań pomocowych skierowane w stronę osób niepełnosprawnych, wpisane w dwa typy dokumentów strategicznych: Strategii rozwoju jednostki samorządu terytorialnego oraz Strategii rozwiazywania problemów spotecznych. Głównym celem badań pilotażowych jest więc wstępne rozpoznanie problematyki wsparcia społecznego oferowanego przez gminy w powyższych dokumentach strategicznych oraz przyporządkowanie jego szczegółowych form do nadrzędnych typów wsparcia społecznego. Pozyskane w ten sposób informacje pozwolą ocenić przynajmniej częściowo poziom troski oraz pomocy gmin wobec ich niepełnosprawnych mieszkańców. Analiza taka powinna ukazać całe spektrum, kompleksowość działań pomocowych w omawianym zakresie, a także zaangażowanie środowiska lokalnego. 
Problematyka badawcza została określona $\mathrm{w}$ dwóch podstawowych pytaniach:

- Jakie typy wsparcia społecznego stosowane wobec osób niepełnosprawnych można wyodrębnić w analizowanych Strategiach rozwoju gmin i w Strategiach rozwiązywania problemów społecznych?

- Jakie formy szczegółowe przyjmują oferowane typy wsparcia społecznego $\mathrm{w}$ analizowanych Strategiach rozwoju gmin i w Strategiach rozwiazywania problemów spotecznych?

Poszukując odpowiedzi na tak sformułowane pytania analizie typu jakościowego zostały poddane Strategie rozwoju gmin i Strategie rozwiąywania problemów społecznych gmin z dwóch powiatów województwa śląskiego: żywieckiego (15) oraz cieszyńskiego (12)2. Wybór takiego obszaru badań warunkowany był dostępnością do organów odpowiadających za konstruowanie strategii. Analiza dokumentów bazuje na jakościowym opisie i interpretacji zawartych $\mathrm{w}$ dokumentach treści. Uwzględnia zarówno treści jawne jak i ukryte (czyli informacje niewidoczne na pierwszy rzut oka, które badacz odkrywa w wyniku pogłębionej interpretacji i zestawienia ze sobą znajdujących się w dokumentach faktów) analizowanych dokumentów. Próbuje odpowiedzieć na takie pytania: co chciał przedstawić autor danego dokumentu, jakie wyraził w nim treści, o czym mogą one świadczyć, na czym polega ich oryginalność (Łobocki 2006: 222). W przypadku jakościowej analizy treści dokumentów klucz kategoryzacyjny jest określonym wynikiem badania. To pewnego rodzaju lista zagadnień ujmowanych $w$ materialne badawczym, która podkreśla ich maksymalną różnorodność (Szczepaniak 2012: 98-99). W tym jednak przypadku po ich zidentyfikowaniu zostaną one w zamierzeniach badawczych skonfrontowane z typologią wsparcia społecznego zaproponowaną przez Helenę Sęk. W wyniku analizy jakościowej zostanie wstępnie rozpoznana problematyka wsparcia społecznego oferowanego wobec osób niepełnosprawnych w Strategiach rozwoju gmin i w Strategiach rozwiązywania problemów społecznych, a do nadrzędnych typów wsparcia przyporządkowane zostaną bardziej szczegółowe formy lub działania.

\section{Prezentacja i omówienie wyników badań}

Poniżej zaprezentowane zostały $\mathrm{w}$ formach tabelarycznych poszczególne typy wsparcia społecznego znajdujące się w strategiach wraz z przyporządkowanymi do nich uszczegółowionymi formami/działaniami.

$\overline{2}$ Spis analizowanych strategii został umieszczony po bibliografii. Ogółem analizie poddano 3901 stron dokumentów. 
Tabela 1. Wsparcie emocjonalne i jego formy oferowane w Strategiach rozwoju gmin i w Strategiach rozwiązywania problemów społecznych

\begin{tabular}{|l|}
\hline \multicolumn{1}{c|}{ WSPARCIE EMOCJONALNE } \\
\hline - Działalność grup wsparcia dla osób niepełnosprawnych oraz takich form wsparcia jak np.: \\
świetlice, WTZ, dzienne ośrodki wsparcia - oferujące pomoc psychologiczną i pedagogiczną \\
\hline - Działalność Klubów Integracji Społecznej lub stworzenie odpowiednich warunków do ich \\
powstania
\end{tabular}

Źródło: Opracowanie własne.

Tabela 2. Wsparcie informacyjne i jego formy oferowane w Strategiach rozwoju gmin i w Strategiach rozwiązywania problemów społecznych

\section{WSPARCIE INFORMACYJNE (POZNAWCZE)}

- Funkcjonowanie/Tworzenie na terenach gmin tzw. punktów informacyjnych dla osób niepełnosprawnych oraz ich bliskich

- Informowanie nt. możliwości zatrudnienia osób niepełnosprawnych, informowanie nt. ewentualnych wolnych miejsc pracy przez Powiatowe Urzędy Pracy

- Informowanie o możliwości uzyskania pomocy przez osoby niepełnosprawnych oraz ich opiekunów z PCPR, PFRON, PUP, innych czy działających na terenach gmin organizacji pozarządowych

- Rozwój usług społecznych - dostosowanie ich do potrzeb osób niepełnosprawnych

- Wydawanie biuletynów informacyjnych lub tworzenie domen internetowych, zawierających informacje ważne z punktu widzenia osób niepełnosprawnych i ich rodzin

- Udzielanie konsultacji dla osób niepełnosprawnych przez Miejskie Ośrodki Pomocy Społecznej dotyczących praw i przywilejów osób niepełnosprawnych wynikających z obostrzeń prawnych, ich zatrudnieniu, aktywizacji zawodowej, możliwości podjęcia nauki, realizowanych programów oraz przedsięwzięć, których są adresatami oraz o działalności na terenie gminy instytucji wspierających osoby niepełnosprawne

- Zwiększenie dostępu do informacji dla osób niepełnosprawnych na temat udzielanych na terenie gminy formach wsparcia, z których mogą skorzystać

- Zwiększenie społecznej świadomości w zakresie praw osób niepełnosprawnych, poprzez organizowanie kampanii społecznych lub eventów integracyjnych

Źródło: Opracowanie własne 
Tabela 3. Wsparcie instrumentalne i jego formy oferowane w strategiach rozwoju gmin i w strategiach rozwiązywania problemów społecznych

\begin{tabular}{|l|}
\hline \multicolumn{1}{|c|}{ WSPARCIE INSTRUMENTALNE, INSTRUKTAŻOWE } \\
\hline - Aktywizowanie lokalnych społeczności do działań związanych z wolontariatem na rzecz \\
niepełnosprawnych mieszkańców gmin
\end{tabular}

Źródło: Opracowanie własne 
Tabela 4. Wsparcie duchowe i jego formy oferowane w Strategiach rozwoju gmin i w Strategiach rozwiązywania problemów społecznych

\section{WSPARCIE DUCHOWE}

Działalność specjalistycznych instytucji opiekuńczych (hospicja, Domy Pomocy Społecznej), które oprócz usług opiekuńczych gwarantują swoim podopiecznym (także osobom niepełnosprawnym) znajdującym się w szczególnie trudnej sytuacji zdrowotnej, psychicznej możliwość skorzystania z poradnictwa psychologicznego czy usług związanych z posługą kapelańską ze strony wyznaczonych do tego księży oraz realizacja takich form opieki by zapewnić godność i poszanowanie wobec każdej jednostki ludzkiej.

Źródło: Opracowanie własne

Tabela 5. Wsparcia rzeczowe i materialne oraz jego formy oferowane w Strategiach rozwoju gmin i w Strategiach rozwiązywania problemów społecznych

WSPARCIE RZECZOWE I MATERIALNE

Działalność Miejskich Ośrodków Pomocy Społecznej, PCPR, PFRON:

- wsparcie o charakterze finansowym, pracy socjalnej, zasiłki pielęgnacyjne, świadczenia pomocy społecznej z tytułu niepełnosprawności (okresowe, stałe, celowe) - w myśl ustawy o pomocy społecznej;

- wsparcie finansowe z przeznaczeniem na przynajmniej częściowe pokrycie kosztów leczenia i rehabilitacji;

- organizowanie mieszkań treningowych i chronionych;

- możliwość uzyskania dofinansowania do zakupu leków, sprzętu rehabilitacyjnego, przedmiotów ortopedycznych, wczasów i turnusów rehabilitacyjnych, transportu;

- możliwość uzyskania dofinansowania do likwidacji barier architektonicznych, technicznych oraz komunikacyjnych, np. środowisku zamieszkania osoby niepełnosprawnej;

- dofinansowanie do zakupu opału na zimę;

- dofinansowania do pobytu osób niepełnosprawnych w DPS-ach czy innych ośrodkach opieki całodobowej.

Działalność Powiatowych Urzędów Pracy:

- udzielanie dotacji osobom niepełnosprawnym na rozpoczęcie działalności gospodarczej;

- dofinansowaniu do nowo utworzonych stanowisk pracy dla osób niepełnosprawnych;

- organizowanie staży zawodowych dla osób niepełnosprawnych.

Działalność tzw. zakładów pracy chronionej:

- umożliwienie zatrudnienia i zarobku osobom niepełnosprawnym w zindywidualizowanych typowo pod nich warunkach pracy.

Działalność organizacji pozarządowych oraz organizacji społecznych (fundacji, stowarzyszeń, kościoła, innych organizacji działających na rzecz osób niepełnosprawnych):

- gwarantujących świadczenia materialne, organizowanie akcji charytatywnych, wparcie rzeczowe, dofinansowania z projektów unijnych przeznaczone dla osób niepełnosprawnych o szerokim spektrum przeznaczenia.

* Środki przeznaczone na wsparcie rzeczowe (materialne) pochodzą z budżetu Państwa, budżetu samorządu lokalnego, środków unijnych, środków organizacji pozarządowych.

Źródło: Opracowanie własne 
Jak wynika ze zgromadzonego materiału gminy w swoich strategiach przewidują objęcie osób niepełnosprawnych zróżnicowanymi typami wsparcia oraz formami działań pomocowych. Powyższy materiał jest jednak uogólniony, ponieważ częstym przypadkiem jest określanie tej samej formy wsparcia w strategiach za pomocą odmiennych pojęć mających analogiczne znaczenie. Zestawienie nie prezentuje ponadto częstości pojawiających się form wsparcia w poszczególnych jego typach.

W Strategiach rozwoju gmin i w Strategiach rozwiazywania problemów społecznych treści dotyczące wsparcia społecznego wobec osób niepełnosprawnych również nie są uporządkowane. We wspomnianych dokumentach nie dokonano szczegółowego podziału działań wspierających $\mathrm{w}$ odniesieniu do rodzaju i charakteru wsparcia, który oferują. Natomiast kwestie istotne dotyczące tej tematyki pojawiają się $\mathrm{w}$ strategiach zwykle przy określaniu zasobów gminy osadzonych w problematyce niepełnosprawności jej mieszkańców lub w konstruowanych do tego specjalnych analizach SWOT. Obrazują one mocne i słabe strony, a także szanse i zagrożenie w obszarach polityki społecznej dotyczącej niepełnosprawności mieszkańców danej jednostki samorządu terytorialnego. Elementy wsparcia społecznego są obecne także tam gdzie w strategiach określane są cele i działania związane z rozwojem gminy. Są w stosunku do nich mocno analogiczne. Nie jest to jednak nic nietypowego, ponieważ włodarze konstruując cele i bardziej szczegółowe działania powinni je oprzeć na sprecyzowanej podstawie. W przypadku niepełnosprawności oraz innych problemów z pogranicza socjalno-bytowego rodzaje oraz formy wsparcia społecznego taką właśnie podstawę mogą budować.

Podobnie jak cele i zadania także formy wsparcia przyjmują w zapisach strategii formułę ogólną. Zamieszczenie w dokumentach samego postulatu dotyczącego działania wspierającego z punktu widzenia osoby poszukującej pomocy nie jest najbardziej trafnym rozwiązaniem. Brakuje pewnego skonkretyzowania danej formy wsparcia, chociażby przez krótki opis, na czym taka forma ma polegać, jak przebiega lub gdzie należy się udać bądź z jakim podmiotem kontaktować by móc z niej skorzystać.

Na podstawie zgromadzonego materiału można jednak wnioskować, że jednostki samorządu terytorialnego w swoich strategiach proponują dość szeroki zakres działań wspierających przeznaczonych dla osób niepełnosprawnych. Szczególnie rozbudowane jest wsparcie instrumentalne (bądź instruktażowe) oparte na aktywizacji, organizowaniu i działalności różnych przedsięwzięć na rzecz osób niepełnosprawnych. Dobrze świadczy także fakt wielości form wsparcia emocjonalnego oraz informacyjnego. Zwłaszcza to pierwsze z nich wydaje się być istotne do zachowania równowagi emocjonalnej osób znajdujących się w sytuacji trudnej. Opiera się nie tylko na działalności profesjonalnych organizacji pomocowych, ale warunkuje je także społeczna postawa pełnosprawnych mieszkańców 
w stosunku do niepełnosprawności i ich gotowość do udzielania pomocy. Jeżeli chodzi o wsparcie materialne, to związane jest ono przede wszystkim z działalnością na terenie gmin organizacji oferujących pomoc w zakresie socjalno-bytowym, a także podmiotów pozarządowych, które mogą czerpać środki ze źródeł zewnętrznych. Na tle pozostałych pozornie mało rozbudowane jest wsparcie duchowe. Należy jednak zdawać sobie sprawę, że dotyczy ono sytuacji specyficznych, związanych głownie z dobiegającą do końca egzystencją człowieka i łączy się z opieką paliatywną. Dobrze jednak, że i w takich sytuacjach gminy podejmują działania gwarantujące troskę oraz poczucie godności człowieka.

Podsumowując - sporządzenie typologii wsparcia społecznego dotyczącego osób niepełnosprawnych oraz przyporządkowanie do niej szczegółowych form nie było zadaniem łatwym. Dokonując merytorycznej analizy form wsparcia można zauważyć, że niektóre z nich przyjmują wielostronne znaczenie i zaklasyfikowanie ich do danego typu nie jest wcale oczywiste, a bardziej umowne. Mogą się z powodzeniem znajdować $w$ dwóch i więcej kategoriach. Ta pewnego rodzaju płynność i wzajemne nakładanie się na siebie form nie jest jednak niczym zaskakującym bowiem o prawdziwym wsparciu społecznym wobec osób niepełnosprawnych można mówić gdy wszystkie jego komponenty funkcjonują w pewnej symbiozie i zależności. Tworzą wtedy ogólny mechanizm kompleksowego wsparcia o zadawalającej skuteczności.

\section{Podsumowanie}

Problematyka wsparcia społecznego głównie analizowana jest przez pryzmat działalności instytucji, organizacji, specjalnie do tego powołanych grup. Taki stan rzeczy daje się zauważyć również w analizowanych Strategiach rozwoju gmin i Strategiach rozwiązywania problemów społecznych. Coraz częściej jednak duże znaczenie przypisuje się naturalnym układom międzyludzkim. Osoba niepełnosprawna powinna być więc traktowana w perspektywie konkretnego człowieka z konkretnymi potrzebami (Kirenko 2004: 12). Włodarze jednostek samorządu terytorialnego muszą o tym pamiętać oferując działania pomocowe niepełnosprawnym mieszkańcom. Ważna jest nie tylko działalność profesjonalnych organizacji pomocowych, ale to $w$ jakim zakresie będą niepełnosprawni partycypować $w$ otaczającej ich rzeczywistości, zależy też od nastawienia do tej problematyki lokalnych grup społecznych. Konstruowane strategie w zakresie wsparcia osób niepełnosprawnych powinny aktywizować mieszkańców do podejmowania działań pomocowych na ich rzecz, korygować fałszywe wyobrażenia i stereotypy. Dopiero wówczas będziemy mogli mówić o autentycznej kulturze inkluzyjnej. Nie ma 
bowiem jednego, prostego modelu wsparcia społecznego. Sieć społeczna może być zarówno źródłem stresu, ale też buforem przeciwko niemu (Kirenko 2004: 15). Wszystko zależy od tego w jaki sposób i przez kogo zostanie pokierowana. Jednostki samorządu terytorialnego wdrażając nowe oddziaływania wobec osób z niepełnosprawnością mogą stać się inicjatorami zmian, dając lokalnej społeczności dobry przykład. Chwalebne jest to, że w coraz większej mierze ich włodarze podejmują się takiej roli i konstruując lokalną politykę społeczną biorą pod uwagę potrzeby osób niepełnosprawnych oraz adresują do nich zróżnicowane typy i formy wsparcia społecznego.

\section{Bibliografia}

Brzezińska A. I., Kaczan R., Rycielski P. (2010), Układy czynników sprzyjajacych inkluzji i utrudniających inkluzję osób niepetnosprawnych [w:] A.I. Brzezińska, J. Pluta, P. Rycielski (red.), Wsparcie dla osób z ograniczeniami sprawności i ich otoczenia. Wyniki badań, Wydawnictwo Naukowe Scholar, Warszawa.

Encyklopedia Zarządzania, https://mfiles.pl/pl/index.php/Strategia (dostęp: 03.2018).

Fidelus A. (2016), Rola zasobów wewnętrznych i zewnętrznych w modelu relacyjnej inkluzji społecznej [w:] D. Stępkowski, E. Śmiechowska-Petrovskij, K. Krawiecka (red.), Forum Pedagogiczne, nr 1, Uniwersytet Kardynała Stefana Wyszyńskiego w Warszawie.

Gajdzica Z. (2015), Social policy of the local government unit as an initiator of good practices in activating the disabled [w:] I. Fajfer-Kruczek (red.), Osoba niepetnosprawna w środowisku lokalnym, Problemy Edukacji, Rehabilitacji i Socjalizacji Osób Niepełnosprawnych, Katowice, t. 20, Wydawnictwo Uniwersytetu Śląskiego.

Gajdzica Z., Mrózek S. (2017), Cele i zadania działań edukacyjnych w obszarze kształcenia uczniów z niepetnosprawnościq oraz edukacji o niepetnosprawności zawarte w strategiach rozwoju gmin a problem rozwoju edukacji inkluzyjnej [w:] Z. Gajdzica (red.), Studia Pedagogiczne. Wokół wyzwań pedagogicznych, t. LXX, Cieszyn, Wydawnictwo Arka.

Grewiński M., Karwacki A. (2009), Strategia - istota, reguly i wyzwania implementacji ze środowiska biznesu do polityki społecznej [w:] M. Grewiński, A. Karwacki (red.), Strategie w polityce społecznej, publikacja współfinansowana ze środków Europejskiego Funduszu Społecznego w ramach Programu Operacyjnego Kapitał Ludzki, priorytet VII, działanie 7.1.3., Mazowieckie Centrum Polityki Społecznej.

Karwowska M. (2003), Wspieranie rodziny dziecka niepetnosprawnego umystowo (w kontekście społecznych zmian), Oficyna Wydawnicza „Impuls”, Kraków.

Kauffman J.M., McGee K., Brigham M. (2004), Enabling or Disabling? Observations on Changes in Special Education, Phi Delta Kappa International, April.

Kirenko J. (2004), Dylematy wsparcia społecznego osób z niepetnosprawnościa [w:] Z. Palak, Z. Bartkowicz (red.), Wsparcie spoteczne w rehabilitacji i resocjalizacji, Wydawnictwo Uniwersytetu Marii Curie-Skłodowskiej, Lublin.

Kołaczek B. (2010), Polityka społeczna wobec osób niepetnosprawnych, IPiSS, Warszawa. 
Kowalik S. (2005), Psychologiczne podstawy niepetnosprawności i rehabilitacji [w:] J. Strelau (red.), Psychologia. Podręcznik akademicki. Jednostka w społeczeństwie i elementy psychologii stosowanej, t. 3, Gdańskie Wydawnictwo Psychologiczne, Gdańsk.

Lejzerowicz M., Książkiewicz I. (2012), Osoba z niepetnosprawnościq a instytucja pomocowe, Wydawnictwo Gaskor Sp. z o.o., Wrocław.

Łobocki M. (2006), Metody i techniki badań pedagogicznych, Oficyna Wydawnicza „Impuls”, Kraków.

Piorunek M. (red.) (2010), Pomoc-wsparcie społeczne-poradnictwo. Od teorii do praktyki, Wydawnictwo Adam Marszałek, Torun.

Przecławska A., Theiss W. (1996), Pedagogika społeczna: nowe zadania i szanse [w:] A. Przecławska (red.), Pedagogika społeczna - kręgi poszukiwań, Wydawnictwo „Żak”, Warszawa.

Sęk H. (1986), Wsparcie społeczne - co zrobić aby stato się pojęciem naukowym?, Przegląd Psychologiczny, 3, t. 29.

Sęk H., Cieślak R. (2012), Wsparcie społeczne, sposoby definiowania, rodzaje i źródła wsparcia, wybrane koncepcje teoretyczne [w:] H. Sęk, R. Cieslak (red.), Wsparcie społeczne, stres i zdrowie, Wydawnictwo Naukowe PWN, Warszawa.

Sobol E. (red.) (2003), Nowy Stownik Języka Polskiego, Wydawnictwo Naukowe PWN, Warszawa.

Solomon L.J., Rothblum E.D. (1986), Stress, coping, and social support in woman, The Behavior Therapist, 9.

Stońska Z., Misiuna M. (1993), Promocja zdrowia. Słownik podstawowych terminów, Agencja Promo-Lider, Warszawa.

Strelau J. (2003), Psychologia - podręcznik akademicki, t. 3, Gdańskie Wydawnictwo Psychologiczne, Gdańsk.

Szczepaniak K. (2012), Zastosowanie analizy treści w badaniach artykułow prasowych - refleksje metodologiczne, Acta Universitatis Lodziensis Folia Sociologica, nr 42.

Thoits P.A. (1985), Social suport processes and psychological well-being: Theoretical posibilities [w:] Social support: Theory research and applications, I.G. Sarason, B.R. Sarason (red.), Dorgrecht, Martinus Nijhoff.

\section{Spis analizowanych strategii}

Strategia Rozwoju Gminy Gilowice na lata 2015-2022; http://www.gilowice.pl/zdjecia/ak/ zal/ strategia-gilowice_201511171402.pdf.

Strategia rozwiązywania problemów społecznych w Gminie Gilowice na lata 2008-2020; http:// mapa-reagujemy.slask.pl/wp-content/uploads/2013/12/STRATEGIA_2008-20_GILOWICE.pdf.

Strategia Rozwoju Gminy Jeleśnia na lata 2015-2020; http://www.jelesnia.pl/strategia-rozwoju-gminy-jelesnia-na-lata-2015-2020,24,akt.

Strategia rozwiąywania problemów społecznych w Gminie Jeleśnia na lata 2013-2017; http:// www.bip.jelesnia.pl/index.php?modul=aktualnosci\&kat_id $=46 \& i d=2850$.

Strategia Rozwoju Gminy Łodygowice na lata 2014-2020; http://www.lodygowice.pl/i/images/ file/bar573.pdf. 
Strategia Rozwiazywania Problemów Społecznych Gminy Łodygowice na lata 2014-2024; http:// www.lodygowice.pl/!data/dokumenty/program\%20pomocy $\% 20 \mathrm{dziecku} \% 20 \mathrm{i} \% 20 \mathrm{rodzi}$ nie.pdf.

Strategia Rozwiazywania Problemów Społecznych dla Gminy Łękawica na lata 2016-2025; http:// www.bip.lekawica.com.pl/index.php?modul=aktualnosci\&kat_id=309\&id=2792.

Strategia Rozwoju Gminy Lipowa do 2020 roku; http://www.lipowa.pl/assets/lipowa/media/ files/d2878fcf-11a9-4cb9-8411-0f4e05f77c12/strategia-rozwoju-gminy-lipowa-projekt.pdf.

Strategia Integracji i Rozwiazywania Problemów Społecznych Gminy Lipowa na lata 2011-2017; http://bip.lipowa.pl/uchwala-nr-viii-33-11-w-sprawie-przyjecia-strategii-integracji-irozwiazywania-problemow-spolecznych-gminy-lipowa-na-lata-2011-2017.

Strategia Rozwoju Gminy Ślemień na lata 2014-2022; http://slemien.pl/images/Artyku\%C5\% 82/Za\%C5\%82\%C4\%85cznik_do_uchwa\%C5\%82y_VIII.33.2015.pdf.

Strategia Rozwoju Gminy Milówka na lata 2015-2025; www.milowka.pl/download/257.html.

Strategia Integracji i Rozwiazywania Problemów Społecznych w Gminie Milówka na lata 20142020; http://www.bip.milowka.com.pl/BIP.aspx?Sel=5845\&ident=5240\&amp;js=1.

Strategia Integracji $i$ Rozwiazywania Problemów Społecznych Gminy Weegierska Górka na lata 2014-2020; http://www.bip.wegierska-gorka.pl/index.php?modul=aktualnosci\&kat_id= $230 \& \mathrm{id}=2132$.

Strategia Integracji i Rozwiazywania Problemów Społecznych Gminy Świnna na lata 2015-2020; http://mapa-reagujemy.slask.pl/mapa/swinna/.

Strategia Rozwoju Gminy Rajcza na lata 2014-2020; http://www.rajcza.pl/zdjecia/ ak/zal/ strategia-12-11-2015_201511131334.pdf.

Strategia Rozwiazywania Problemów Społecznych Gminy Ujsoły na lata 2014-2020; http://www. bip-gops.ujsoly.com.pl/index.php?modul=aktualnosci\&kat_id=11\&id=31.

Program Rozwoju Gminy Radziechowy-Wieprz na lata 2016-2027; http://www.radziechowywieprz.pl/upload/statement/22/files/422/program-rozwoju-gminy-radziechowy-wieprzna-lata-2016-2027.pdf.

Strategia Rozwiazywania Problemów Społecznych w Gminie Radziechowy-Wieprz na lata 20142020; http://gopswieprz.pl/wp-content/uploads/2017/07/STRATEGIA-2014-2020-pdf.pdf.

Strategia Rozwiazywania Problemów Społecznych Gminy Koszarawa na lata 2016-2020; http://bip.gwkoszarawa.finn.pl/res/serwisy/pliki/13492422?version=1.0.

Strategia Integracji i Rozwiazywania Problemów Społecznych Gminy Czernichów na lata 20142018; http://mapa-reagujemy.slask.pl/wp-content/uploads/2013/12/STATEGIA_2014_ 20_CZERNIOCHOW.pdf.

Strategia Zrównoważonego Rozwoju Społeczno-Gospodarczego Powiatu Żywieckiego na lata 2006-2020; http://bippzzywiec.finn.pl/res/serwisy/bippzzywiec/komunikaty/_007_002_405638.pdf.

Powiatowa Strategia Rozwiazywania Problemów Społecznych w Powiecie Żywieckim; http://www.pcpr-zywiec.pl/images/stories/zalaczniki/Strategia.pdf.

Strategia Rozwiazywania Problemów Społecznych dla Miasta Żywca na lata 2014-2020; http:// www.bip.zywiec.pl/index.php?modul=aktualnosci\&kat_id=54\&id=3597.

Strategia Rozwoju Gminy Brenna do 2020 roku; http://www.bip.brenna.org.pl/?c=mdTresccmPokaz-189.

Strategia Rozwiazywania Problemów Społecznych w Gminie Brenna na lata 2014-2020; www.bip.brenna.org.pl/?c=mdPliki-cmPobierz-8092... 
Strategia Rozwoju Gminy Chybie na lata 2015-2025; http://www.chybie.pl/asp/pliki/aktualnosci/2016_03_02_strategia_gminy_chybie.pdf.

Gminna Strategia Rozwiazywania Problemów Społecznych na lata 2014-2020; www.gops.chybie.samorzady.pl/att/?id=53c4023896ac69025ae982c6885dd1af.

Strategia Rozwoju Gminy Dębowiec na lata 2016-2025; http://www.debowiec.bip.info.pl/ dokument.php?iddok=4353\&idmp=102\&r=r.

Strategia Rozwiazywania Problemów Społecznych w Gminie Dębowiec na lata 2012-2020; http://mapa-reagujemy.slask.pl/wp-content/uploads/2013/11/Strategia-Rozwi\%C4\%85 zywania-Problem\%C3\%B3w-Spo\%C5\%82ecznych-w-Gminie-D\%C4\%99bowiec-nalata-2012-2020.pdf.

Strategia Rozwiązywania Problemów Społecznych Gminy Goleszów na lata 2016-2020; http://www.gops-goleszow.pl/files/Zarzadzenie\%20nr\%200050.102.2016.pdf.

Strategia Rozwoju Gminy Goleszów na lata 2016-2026; http://www.goleszow.bip.net.pl/ ?a $=9914$.

Strategia Rozwoju Gminy Hażlach na lata 2011-2020; http://www.hazlach.samorzady.pl/art/ $\mathrm{id} / 3004$.

Strategia Rozwiazywania Problemów Społecznych Gminy Hażlach na lata 2011-2020; http://mapa-reagujemy.slask.pl/wpcontent/uploads/2013/11/Strategia_Rozwi\%C4\%85zywania-Problem\%C3\%B3wSpo\%C5\%82ecznych-wraz-z-programami.pdf.

Gmina Istebna Strategia Rozwoju 2020; http://e-bip.pl/Start/23464/Information/222667.

Gminna Strategia Rozwiazywania Problemów Społecznych w Gminie Istebna na lata 2016-2022; www.istebna.bip.info.pl/plik.php?id=7857.

Strategia Rozwoju Gminy Zebrzydowice do roku 2020; http://www.zebrzydowice.bip.info. pl/dokument.php?iddok=6794\&idmp=77\&r=r.

Strategia Rozwiazywania Problemów Społecznych Gminy Zebrzydowice na lata 2011-2017; www.zebrzydowice.bip.info.pl/dokument.php?iddok=4260\&idmp=8\&r=r.

Strategia Rozwoju Miasta i Gminy Strumień na lata 2014-2022; http://www.strumien.bip. net.pl/?c=338.

Strategia Rozwiazywania Problemów Społecznych w Gminie Strumień na lata 2011-2018; http://mapa-reagujemy.slask.pl/mapa/strumien/.

Strategia Rozwoju Gminy Skoczów na lata 2014-2020; http://bip.skoczow.pl/uchwala-nr-xli528-2014-w-sprawie-przyjecia-startegii-rozwoju-gminy-skoczow-na-lata-2014-2020/ porownaj/3/2.

Strategia Rozwiazywania Problemów Społecznych dla Gminy Skoczów na lata 2014-2020; http://bip.skoczow.pl/uchwala-nr-xxxv-454-2013-w-sprawie-przyjecia-gminnej-strategiirozwiazywania-problemow-spolecznych-dla-gminy-skoczow-na-lata-2014-2020.

Strategia Rozwoju Miasta Wisła do 2020 roku; http://docplayer.pl/10805945-Strategia-rozwojumiasta-wisla-na-lata-2014-2022-1-s-t-r-o-n-a.html.

Gminna Strategia Rozwiazywania Problemów Społecznych w Mieście Wisła na lata 2016-2024; http://www.prawomiejscowe.pl/api/file/GetZipxAttachment/254/501233/preview.

Strategia Rozwoju Miasta Ustroń do 2020 roku; http://www.zgloszenia.ustron.pl/media/ page/ 332/attachment/Strategia \%20Rozwoju\%20Miasta\%20Ustro\%C5\%84\%20do\%202020\%20 roku.pdf. 
Strategia Rozwiazywania Problemów Społecznych Gminy Ustroń na lata 2016-2020; www.ustron.bip.info.pl/plik.php?id=33648.

Strategia Rozwoju Miasta Cieszyna na lata 2010-2020; http://www.cieszyn.pl/?p=categories Show\&iCategory $=158$.

Gminna Strategia Rozwiazywania Problemów Społecznych Miasta Cieszyna na lata 2014-2020; http://mapa-reagujemy.slask.pl/wp-content/uploads/2013/11/strategia_2014_20_cieszyn.pdf. 